\title{
ЗД-14 \\ СОРБЦИОННОЕ КОНЦЕНТРИРОВАНИЕ ПЛАТИНОВЫХ МЕТАЛЛОВ В УЛЬТРАЗВУКОВОМ ПОЛЕ
}

Данилова Т.В., Моходоева О.Б., Дженлода Р.Х., Шкинев В.М., Спиваков Б.Я. ФГБУН Институт геохимии и аналитической химии им. В.И. Вернадского РАН,

Москва, Россия

dzhenloda@gmail.com

DOI: 10.26902/ASFE-11_152

Ультразвук широко используют в пробоподготовке, в том числе для интенсификации фильтрационных, экстракционных и сорбционных процессов. Ранее нами предложен способ сорбционного концентрирования ионов металлов с использованием ультразвуковых суспензионных (УЗС) колонок [1-2], позволяющий удерживать в потоке жидкости суспензию мелкозернистого сорбента без применения фильтров. Ультразвуковое воздействие, создаваемое в колонках, влияет также на кинетику сорбции веществ за счет возникающих микротурбулентных акустических течений, которые создают условия для ускоренного протекания сорбции благодаря интенсификации массопереноса в системе сорбат-сорбент.

В настоящей работе продемонстрирована возможность использования УЗС колонок (рис.) для повышения эффективности извлечения платиновых металлов на стадиях сорбции из многокомпонентных хлоридных растворов и последующей десорбции с получением индивидуальных растворов целевых компонентов. В качестве сорбента использовали силикагель Kromasil Sil, состоящий из идеально сферических частиц определенного размера (5 мкм), модифицированный фосфониевой ионной жидкостью Cyphos IL 101. Определены оптимальные условия для селективного выделения платины (IV) и палладия (II) в УЗС колонке: 0.1-1 M HCl, 10-60 г/л $\mathrm{Cl}^{-}$, содержание ионной жидкости 0.3 ммоль/г, скорость пропускания раствора 0.5 мл/мин, масса сорбента 0,02 г, интенсивность ультразвукового излучения $10^{5} \mathrm{BT} / \mathrm{M}^{2}$.

Известно, что элюирование платиновых металлов обычно затруднено. Нами показано, что в условиях УЗС колонки существенно увеличивается эффективность десорбции платиновых металлов. Так, при использовании в качестве элюента перхлората натрия (0.5 M) и скорости пропускания раствора 0.2 мл/мин обеспечивается количественное извлечение металлов из фазы сорбента.

Разработанная методика сорбционного концентрирования платины и палладия апробирована на примере модельного хлоридного раствора, содержащего ионы благородных, тяжелых и других элементов, с последующим определением металлов методами МС-ИСП и АЭС-ИСП.

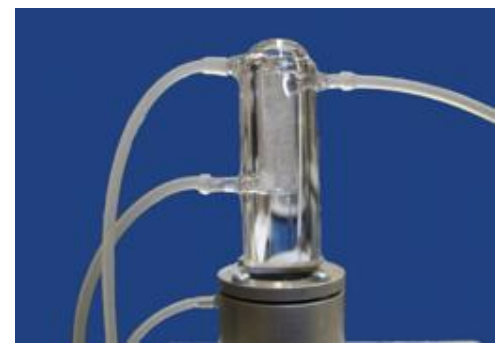

Рис. 1 Ультразвуковая суспензионная колонка (диаметр 10 мм, длина 50 мм, масса сорбента 0,02 г)

\section{Список литературы}

1. Spivakov B.Ya., Shkinev V. M., Danilova T.V., Knyazkov N. N., Kurochkin V. E., Karandashev V.K. Suspension column for recovery and separation of substances using ultrasound-assisted retention of bead sorbents // Talanta. 2012. № 102. Р. 88-92.

2. Дженлода Р.Х., Шкинев В.М., Данилова Т.В., Темердашев 3.А., Карандашев В.К., Спиваков Б.Я. Суспензионные колонки с удерживаемыми в ультразвуковом поле зернистыми сорбентами для выделения и определения редкоземельных элементов в винах // Журн. аналит. химии. 2015. Т.70. № 12. С. 1264-1270. 